\title{
Neuroendocrine activation after myocardial infarction: causes and consequences
}

\author{
John G F Cleland, Peter J Cowburn, Kevin Morgan
}

Increases in plasma concentrations of a number of neuroendocrine substances are well documented after myocardial infarction. The objectives of this paper are to describe the time course of neuroendocrine activation after myocardial infarction, the evidence for activation of the cardiac renin-angiotensin system, possible causes and consequences of neuroendocrine activation, the influence of patient genotype on outcome, and the ability of early neuroendocrine activation to predict prognosis.

\section{The time course of neuroendocrine activation}

Plasma concentrations of renin, angiotensin II, and aldosterone are generally increased by the time patients suffering from myocardial infarction are admitted to the hospital. ${ }^{1-4}$ In patients with uncomplicated myocardial infarction, studies have suggested that plasma concentrations of renin, angiotensin II, and aldosterone rise only slightly before returning to normal levels during the first three days following infarction. However, in patients developing heart failure requiring diuretics, activation is exaggerated and sustained. ${ }^{1-3}$ Patients who have sustained large infarcts but who have not required diuretic therapy also have increased renin-angiotensin-aldosterone system (RAAS) activity up to two weeks after infarction, ${ }^{56}$ but probably not in the long term..$^{7-10}$ Plasma angiotensin converting enzyme (ACE) activity does not change, ${ }^{2}$ suggesting that activation of renin rather than ACE is responsible for the rise in angiotensin II after infarction. The possibility that tissue RAAS is activated after myocardial infarction is discussed in more detail below.

Plasma concentrations of noradrenaline and adrenaline are also raised early after infarction and decline progressively thereafter. ${ }^{13}$ Mean levels are still slightly above those of control groups at discharge in patients with uncomplicated myocardial infarction. ${ }^{1}$ Regardless of diuretic treatment, patients sustaining large infarctions have raised noradrenaline levels that can remain high 14 days after infarction. ${ }^{56}$ In contrast to plasma renin, plasma concentra-

\section{Glossary of trials}

CONSENSUS II-Cooperative New Scandinavian Enalapril Survival Study II

SAVE-Survival and Ventricular Enlargement Study tions of noradrenaline remain elevated in patients with chronic asymptomatic left ventricular dysfunction ${ }^{10}$ or untreated heart failure..$^{7-9}$ Plasma concentrations of neuropeptide Y, a substance co-secreted with noradrenaline from sympathetic nerve terminals, are also markedly raised initially. Neuropeptide Y concentrations peak approximately eight hours after myocardial infarction and return to the normal range within two to three days unless heart failure supervenes, in which case they may become chronically elevated in patients suffering from heart failure. ${ }^{112}$ Cardiac sympathetic activity, measured by noradrenaline spillover, is also increased in unstable angina. ${ }^{13}$

Plasma concentrations of antidiuretic hormone $(\mathrm{ADH})$ are markedly raised early after infarction but decline rapidly. ${ }^{14} \mathrm{ADH}$ is raised in patients with chronic asymptomatic left ventricular dysfunction, suggesting that the hormone is chronically activated after large infarctions. ${ }^{10}$

Plasma concentrations of endothelin are also raised in patients suffering from myocardial infarction. ${ }^{15}{ }^{16}$ The values are elevated immediately after infarction and tend to increase further in the ensuing hours, before subsiding to normal levels over the following weeks, unless complications occur. ${ }^{17-19}$

Patients suffering from myocardial infarction have raised plasma concentrations of atrial natriuretic factor (ANF) upon admission to the hospital. The values commonly fall within the first few hours after admission, ${ }^{20-22}$ but rise back to admission levels and remain elevated thereafter. ${ }^{214} 23$ In patients with small infarcts, ANF concentrations may return to the upper limit of the normal range over the following two weeks. Plasma ANF remains distinctly elevated in patients sustaining large infarctions even during long term follow up, ${ }^{210}$ regardless of the development of heart failure.

The pattern of activation of brain natriuretic peptide (BNP) after myocardial infarction appears different from that of ANF; plasma concentrations climb steadily over the first 24 hours. ${ }^{21}$ In patients with smaller infarcts, plasma BNP declines after the first 24 hours but does not reach normal levels until at least four weeks after the infarction. In patients with larger infarcts there appears to be a secondary peak in BNP around the fifth day and plasma BNP remains elevated long term..$^{21} 24$

$\mathrm{N}$-terminal ANF (NT-ANF) is also raised during myocardial infarction. Plasma concentrations of NT-ANF reach a peak four days after infarction and return to the normal range (in uncomplicated cases) within two weeks. ${ }^{25}$ 


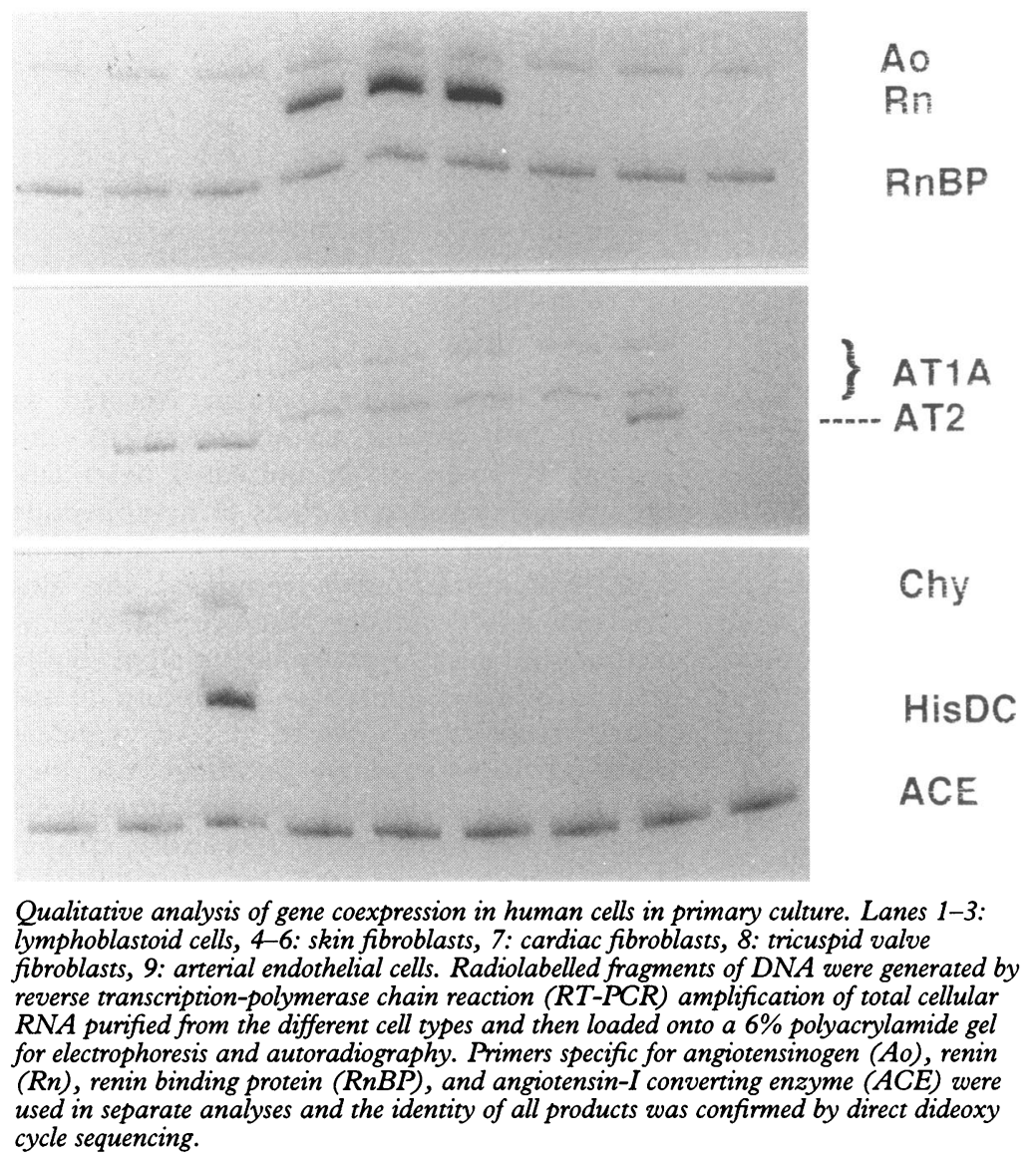

In contrast to C-terminal ANF (CT-ANF), NT-ANF does not appear to show an early decline. ${ }^{26}$ In patients with chronic asymptomatic left ventricular dysfunction NT-ANF remains elevated. ${ }^{27} 28$

\section{ACTIVATION OF THE CARDIAC RENIN- ANGIOTENSIN-ALDOSTERONE SYSTEM IN MYOCARDIAL INFARCTION}

The primary stimuli inducing tissue RAAS activation are obscure. Massive changes in the activity of the plasma RAAS caused by hypoperfusion of key organs (lung, kidney, and liver) may perturb the local intracardiac system. Alternatively, increases in the levels of numerous growth factors and distress molecules within damaged tissue may alter angiotensin turnover.

The rat infarct model shows that homeostatic regulation of the intracardiac RAAS is significantly disturbed following myocardial infarction. Angiotensin binding is dramatically increased at the site of infarction, ${ }^{29}$ and ACE production is induced in endothelial cells within the vicinity of the tissue damage. ${ }^{30}$ Localised activation of angiotensinogen production probably occurs, but it is still unclear whether renin production is induced locally.

A variety of cell types responds to trauma and contributes to a dynamic cardiac repair process. Endothelial cells and vascular smooth muscle cells are activated and begin to proliferate. Fibroblasts, tissue mast cells, and macrophages are also activated. Cellular debris is processed within granulation tissue, and scar tissue is generated and revascularised. Rapid changes in the levels of angiotensin peptides at the site of infarction may exert complex effects on RAAS component production in the surrounding tissue. ${ }^{31}$ Mechanical stress on the surviving myocardium may exert a global effect on stretch regulated genes ${ }^{32}$ depending on the size of the infarct.

The losartan sensitive angiotensin II type 1 receptor (AT-1) subtype is specifically induced in rat infarct scar tissue at an early stage after infarction, but identifying the cell types expressing increased levels of receptor is difficult. Receptor localisation has been correlated with production of markers of tissue repair such as collagen, but further studies at the cellular, protein, and gene expression levels are required to increase our understanding of the rat infarct model. ${ }^{33} 34$

\section{STUDIES OF HUMAN TISSUE}

Analysing human cardiac tissue is more difficult than studying a whole rat heart or its individual chambers. Technical problems exist with respect to the physical size of the human heart and selection of appropriate tissue samples for analysis. As indicated above, activation of the myocardial RAAS may be associated with granulation tissue, inflammation, aging scar tissue, and mechanical stretch in different regions of the same chamber. Old scar tissue might be biochemically distinct from recently repaired sites of necrosis. Important mechanistic clues concerning the function of the human cardiac RAAS post-infarction are therefore likely to be unravelled by cell culture studies capable of mimicking different physiological conditions. ${ }^{3536}$ Some human cells can express all components of the RAAS (figure), suggesting the existence of an autocrine system. Other cell types can express only a limited number of components, indicative of their involvement in a system subject to paracrine regulation.

\section{Causes of plasma neuroendocrine} activation after myocardial infarction

Myocardial infarction is painful, provokes intense anxiety, and is often associated with tachycardia and sometimes hypoxia. It may cause a fall in cardiac output and renal perfusion which leads to activation of arterial baroreflexes. In addition, myocardial infarction causes a rise in left ventricular diastolic pressure and therefore atrial pressures, and is treated with a cocktail of agents. All of these effects are likely to alter neuroendocrine function. In addition, as the heart is itself a neuroendocrine organ, local damage may alter its secretory function.

\section{PAIN, ANXIETY, AND OPIATES}

Pain and anxiety are potent stimuli to sympathetic activation. Relief of pain is likely to be an important factor in reducing early sympathetic activation, but opiates are a powerful stimulus to $\mathrm{ADH}$ release. ${ }^{1}$

NEUROENDOCRINE CONSEQUENCES OF SYMPATHETIC ACTIVATION

Sympathetic activation stimulates renal renin release; therefore plasma renin correlates with 
plasma noradrenaline. ${ }^{137}$ Tachycardia resulting from increased sympathetic activity could also lead to an increase in ANF.

\section{ARTERIAL BAROREFLEX ACTIVATION}

A decrease in arterial pressure leads to baroreflex activation and an increase in sympathetic activation. Head-up tilt activates arterial baroreflexes and increases plasma noradrenaline. The rise in plasma noradrenaline with head-up tilt appears to be increased late (one month) after myocardial infarction. This is associated with an exaggerated increase in angiotensin II. ${ }^{2}$ This is somewhat surprising and awaits confirmation, as arterial baroreflexes have been reported to be blunted after myocardial infarction and in heart failure.

Exercise also increases plasma ANF, renin, and noradrenaline. The increase in ANF levels during exercise appears exaggerated in patients two to three weeks after infarction. The increases in renin and noradrenaline are not significantly different from those found in healthy controls. ${ }^{38}$

\section{Renal vasoconstriction}

Renal vasoconstriction is well documented after infarction and initially reflects sympathetic activation. ${ }^{39}$ Once renal vasoconstriction has occurred this stimulates secretion of renin. The resulting increase in angiotensin II causes further renal vasoconstriction.

\section{Increased ventricular filling/atrial pressure}

Due to the loss of forward stroke volume and a decline in the compliance of infarcted and ischaemic myocardium, ventricular filling and atrial pressure rise. A rise in right and left filling pressures is likely to be a major determinant of ANF secretion, ${ }^{4041}$ possibly especially right ventricular filling. Some investigators have noted an early decline in plasma concentrations of ANF following myocardial infarction..$^{214202123}$ There are several possible explanations for this phenomenon. One theory suggests that early secretion depletes the stored supply of preexisting ANF. Increases in plasma ANF concentrations that are observed several hours after myocardial infarction are due to synthesis of new ANF stimulated by a rise in ventricular filling pressure. Another theory suggests that early cardiac dilatation is limited by pericardial constraint; as ANF secretion reflects the transmural pressure gradient rather than the intracardiac pressure, this could be an important modulating effect. Alternatively, administration of vasodilator agents such as nitrates, ACE inhibitors, and streptokinase, may offload the ventricle and lead to a transient dip in the stimulus to ANF secretion. None of these explanations is entirely satisfactory as the changes in ANF do not seem to be closely accompanied by changes in BNP or NTANF.21 25

Increases in right atrial pressure should attenuate the increase in $\mathrm{ADH}$ and renin that is seen in patients suffering from myocardial infarction, mediated vagally through low pressure baroreceptors or through ANF and BNP. ${ }^{42} 43$ If marked increases in venous pressure occur, the resulting hepatic congestion will impair aldosterone catabolism, leading to a rise in plasma aldosterone.

\section{Hypoxia}

This is a not uncommon finding after myocardial infarction. It probably reflects both opiateinduced hypoventilation and a fall in pulmonary diffusion capacity. ${ }^{4}$ Hypoxia is a powerful stimulus to sympathetic activation.

\section{Effects of treatment \\ THROMBOLYSIS}

Streptokinase is a powerful vasodilator ${ }^{20}$ which activates arterial baroreflexes, leading to an increase in plasma renin, angiotensin II, and catecholamines. ${ }^{20}$ Tissue plasminogen activator is not associated with vasodilation or hypotension or further activation of the RAS. ${ }^{4}$ The administration of an ACE inhibitor within a few hours of streptokinase is likely to aggravate hypotension. This may be one reason why the administration of ACE inhibitors shortly after myocardial infarction may be less effective in reducing mortality. ${ }^{45}$ The effects of thrombolysis on ANF are controversial, but streptokinase probably reduces ANF as discussed above. ${ }^{2022}$ In the long term, thrombolysis, by reducing ventricular damage, should reduce neuroendocrine activation. ${ }^{22}$

\section{NITRATES}

Nitrates reduce filling pressures and arterial pressure and therefore ANF. Cautious use of nitrates may not increase renin or sympathetic activity; however, increases may occur when hypotensive doses are given. ${ }^{42}$

\section{DIURETICS}

Diuretics reduce ventricular filling pressures and circulating volume. Consequently, diuretics reduce ANF and activate the reninangiotensin and the sympathetic nervous system. ${ }^{42} 46$

\section{ASPIRIN}

Although early aspirin treatment has a clearly beneficial effect after myocardial infarction, the possibility that long term aspirin may be harmful in patients who subsequently develop heart failure has been raised. ${ }^{47}$ This may be due to inhibition of vasodilator prostaglandin synthesis.

\section{$\beta$ BLOCKERS}

Cross sectional studies suggest that patients treated with $\beta$ blockers have lowered plasma renin activity but that resting ANF and noradrenaline values are similar to those in nontreated patients. ${ }^{38} 48$ During exercise, patients treated with $\beta$ blockers have suppressed renin, increased plasma concentrations of ANF, and unchanged plasma noradrenaline.

\section{CALCIUM ANTAGONISTS}

There is little post-infarction data on the use of calcium antagonists. In heart failure, calcium 
antagonists generally increase renin-angiotensin and sympathetic nervous system activity ${ }^{42}$ It is unclear whether newer dihydropiridine calcium antagonists have a similar effect on these systems.

\section{ACE INHIBITORS}

ACE inhibitors inhibit the production of angiotensin $\mathrm{II}^{49}$ and reduce plasma concentrations of aldosterone and noradrenaline ${ }^{49}$ in the early hours after infarction. In patients who have sustained large infarcts, ACE inhibitors suppress the sustained increase in angiotensin II and aldosterone..$^{50}$ However, in patients with uncomplicated infarcts, it is difficult to determine the continuing effect of ACE inhibitors because neuroendocrine variables decline naturally in the days following myocardial infarction. $^{2351}$ The natriuretic peptides are markers of ventricular dysfunction and, as ACE inhibitors have beneficial effects on remodelling, it is not surprising that some studies ${ }^{245152}$ suggest that ACE inhibitors reduce levels of natriuretic peptides, though there are exceptions. ${ }^{50}$ There is no rebound increase in NT-ANF after withdrawal from six months of treatment with enalapril. ${ }^{52}$

\section{Effects of genotype}

The DD polymorphism of the ACE gene is associated with higher circulating levels of ACE which could influence post-infarction remodelling. The DD genotype is associated with a greater increase in plasma noradrenaline in the early hours of infarction and a more marked degree of long term cardiac dilatation. ${ }^{53}$ The ACE inhibitor captopril prevented these effects of the DD genotype, suggesting that the increase in plasma ACE associated with the DD genotype is of functional significance. ${ }^{53}$

\section{Consequences of neuroendocrine} activation after myocardial infarction

These have been discussed in more detail in a previous supplement to the British Heart Fournal. ${ }^{54}$

\section{VENTRICULAR REMODELLING}

Activation of neuroendocrine systems has been held responsible for adverse ventricular remodelling after myocardial infarction. Patients with large infarcts are more likely to have progressive ventricular dilatation, develop heart failure, and die. These patients are also more likely to have activation of neuroendocrine systems and therefore an association between activation and remodelling seems inevitable.

Increases in angiotensin II have a positive inotropic effect, can cause cardiac myocyte necrosis with replacement fibrosis and cardiac myocyte hypertrophy, and can stimulate fibroblast proliferation and collagen synthesis. Aldosterone may also have an independent effect on collagen deposition. The RAAS may play an important role in the maturation of the infarct scar with a potentially favourable effect. Increases in catecholamines may also cause cardiac myocyte necrosis. It is not clear if the natriuretic peptides have an important effect on cardiac remodelling.
Although ACE inhibitors exert a favourable effect on ventricular remodelling, it is not certain whether this reflects solely their effect on haemodynamics or also a more direct action on the myocardium.

\section{Vascular effects}

Increases in angiotensin II, sympathetic activity, and $\mathrm{ADH}$ cause arterial constriction, which increases the afterload on the damaged heart. Increases in afterload may result in an increase in preload, as the damaged ventricle fails to discharge its contents adequately. This leads to ventricular dilatation. Local arteriolar constriction at the site of infarction may also be beneficial, by helping to prevent haemorrhage into the infarct. Sympathetic activation has powerful venoconstrictor effects that may be enhanced by angiotensin II and $\mathrm{ADH}$. This results in an exacerbation of the rise in preload. ANF and $\mathrm{BNP}$, as well as increases in vasodilator prostaglandins and nitric oxide, limit vasoconstriction but are overwhelmed when heart failure occurs. Vasoconstriction may be superseded by structural changes in vascular architecture in the systemic and pulmonary circulations that may be difficult or impossible to reverse. It is likely that neuroendocrine activation plays an important role in the transition from functional to structural increases in vascular resistance.

\section{Renal effects}

The cause of salt and water retention in human heart failure is unknown. Animal experiments suggest that the RAAS or sympathetic nervous system may be critical to the development of renal sodium and water retention. Aldosterone antagonists, ACE inhibitors, or drugs that interfere with the sympathetic nervous system do not prevent salt and water retention in heart failure. Only one study of ACE inhibitors in heart failure has noted a reduction in body weight compared to placebo. ${ }^{55}$ Although ACE inhibitors improve renal blood flow in myocardial infarction ${ }^{39}$ and in heart failure, ${ }^{43}{ }^{46}$ they impair glomerular filtration.

\section{Effects on arrhythmias}

The effect of angiotensin II on arrhythmias remains controversial, although most postinfarction studies have shown that ACE inhibitors reduce ventricular arrhythmias. ${ }^{456}$ There is considerable evidence that sympathetic activation is arrhythmogenic. Activation of both the RAAS and the sympathetic nervous system is capable of producing hypokalaemia and inhibition of aldosterone formation, or the $\beta_{2}$ receptor may be beneficial in this respect.

\section{Neuroendocrine activation and prognosis} Data from the SAVE and CONSENSUS II studies and a series of smaller studies have related neuroendocrine variables to prognosis after infarction. ${ }^{11285762}$ These data could be used in at least three ways. First, neuroen- 
Table 1 Relation between neuroendocrine activation and prognosis after myocardial infarction

\begin{tabular}{|c|c|c|c|c|c|c|c|}
\hline \multirow[b]{2}{*}{ Author/year } & \multirow[b]{2}{*}{$n$} & \multirow{2}{*}{$\begin{array}{l}\text { Excluded therapies } \\
\text { at sampling } \\
\text { stratification }\end{array}$} & \multirow{2}{*}{$\begin{array}{l}\text { Sampling } \\
\text { day }\end{array}$} & \multirow[b]{2}{*}{ Follow up } & \multirow[b]{2}{*}{ Variables } & \multicolumn{2}{|c|}{ Prognostic significance } \\
\hline & & & & & & Univariate & Multivariate \\
\hline Svanegaard $/ 92^{57}$ & 55 & $\begin{array}{l}\text { No "vaso active" } \\
\text { drugs }<200 \mathrm{pg} / \mathrm{ml}>\end{array}$ & Admission & 36 & $\begin{array}{l}\text { ANF } \\
\text { Killip class }\end{array}$ & $\begin{array}{l}P=0.006 \\
P=0.014\end{array}$ & $\begin{array}{l}\text { NS } \\
\text { NS }\end{array}$ \\
\hline Omland $/ 93^{\star 60}$ & 145 & $<$ median $>$ & Day 3 & 12 & $\begin{array}{l}\text { ANF } \\
\text { Noradrenaline } \\
\text { Adrenaline }\end{array}$ & $\begin{array}{l}\mathrm{P}<0.001 \\
\mathrm{P}=0.009 \\
\mathrm{P}=0.048\end{array}$ & $\begin{array}{l}P<0.05 \\
N S \\
N S\end{array}$ \\
\hline Omland $/ 93^{\star 61}$ & 139 & $<$ Varied $>$ & Day 3 & 12 & $\begin{array}{l}\text { NT-ANF } \\
\text { ANF } \\
\text { Killip class }\end{array}$ & $\begin{array}{l}P=0.0003 \\
P=0.0004 \\
P=0.001\end{array}$ & $\begin{array}{l}P=0.003 \\
\text { NS } \\
\text { NS }\end{array}$ \\
\hline Omland/94 & 142 & $<75$ th Centile $>$ & Day 3 & 12 & $\begin{array}{l}\text { Endothelin } \\
\text { ANF } \\
\text { Killip class }\end{array}$ & $\begin{array}{l}P<0.0001 \\
P=0.013 \\
P=0.0025\end{array}$ & $\begin{array}{l}\mathrm{P}<0.0001 \\
\text { NS }\end{array}$ \\
\hline $\begin{array}{l}\text { Omland/95 } 95^{\star 58} \\
\text { Echo SS }\end{array}$ & $\begin{array}{r}145 \\
85\end{array}$ & $<$ Median $>$ & Day 3 & 43 & $\begin{array}{l}\text { ANF } \\
\text { Endothelin } \\
\text { Noradrenaline } \\
\text { Killip class } \\
\text { LVEF }\end{array}$ & $\begin{array}{l}P<0.0001 \\
P<0.001 \\
P=0.0335 \\
P<0.0001 \\
P<0.001\end{array}$ & $\begin{array}{l}N S \\
N S \\
N S \\
P=0.02 \\
P<0.01\end{array}$ \\
\hline Rouleau/94 $t^{62}$ & 534 & $\begin{array}{l}\text { ACE Inhibitors } \\
<\text { values in the top } \\
2 \cdot 5 \% \text { of the normal } \\
\text { population }>\end{array}$ & Day 12 & 38 & $\begin{array}{l}\text { Renin } \\
\text { Aldosterone } \\
\text { Noradrenaline } \\
\text { Adrenaline } \\
\text { Dopamine } \\
\text { ANF } \\
\text { ADH }\end{array}$ & $\begin{array}{l}P<0.001 \\
P<0.001 \\
P=0.024 \\
N S \\
N S \\
P<0.001 \\
P=0.01\end{array}$ & $\begin{array}{l}P=0.05 \\
N S \\
N S \\
N S \\
N S \\
P=0.006 \\
N S\end{array}$ \\
\hline Hall $/ 94 \dagger^{28}$ & 246 & $\begin{array}{l}\text { ACE Inhibitors } \\
<\text { values in the top } \\
2 \cdot 5 \% \text { of the normal } \\
\text { population }>\end{array}$ & Day 12 & 32 & NT-ANF & $P<0.001$ & $P=0.012$ \\
\hline Ullman/94 & 113 & $<60 \mathrm{pmol} / \mathrm{l}>$ & Admission & 24 & Neuropeptide Y & $P=0.07$ & NS \\
\hline $\begin{array}{l}\text { Arakawa } / 94^{63} \\
\text { Omland } / 94^{68}\end{array}$ & $\begin{array}{r}70 \\
131\end{array}$ & $\begin{array}{l}<59 \mathrm{pg} / \mathrm{ml}> \\
<75 \text { th Centile }>\end{array}$ & $\begin{array}{l}\text { Admission } \\
\text { Day } 3\end{array}$ & $\begin{array}{l}18 \\
42\end{array}$ & $\begin{array}{l}\text { BNP } \\
\text { BNP } \\
\text { ANP } \\
\text { NT-ANP }\end{array}$ & $\begin{array}{l}P<0.01 \\
P<0.0001 \\
P<0.0001 \\
P=0.0002\end{array}$ & $\begin{array}{l}P=0.0001 \\
P<0.001 \\
\text { NS } \\
\text { NS }\end{array}$ \\
\hline
\end{tabular}

^Substudies of CONSENSUS II

tSubstudies of SAVE.
ANF, atrial natriuretic factor; NT, N-terminal; BNP, brain natuiretic peptide; LVEF, left ventricular ejection fraction.

docrine activation could be used to predict those with major ventricular dysfunction (for example, an ejection fraction of $<40 \%$ ), a subgroup of patients at higher risk of death and in whom long term treatment with ACE inhibitors has been shown to improve prognosis. Second, neuroendocrine variables could themselves be used to identify patients at high risk in whom long term treatment might be appropriate. Third, it is possible that neuroendocrine variables have the ability to identify that subgroup of patients with left ventricular dysfunction who are at especially high risk.

The studies of neuroendocrine variables after infarction show that all are increased to a greater extent in patients with larger infarcts and, perhaps more importantly (as many patients will have more than one infarct), patients with the poorest residual ventricular function. As right and left ventricular infarction may have different effects on haemody- namics and neuroendocrine activation, a strong relation between left ventricular function and neuroendocrine activation is not to be expected. Furthermore, due to the biphasic nature of the increase in some factors, such as ANF and BNP, the timing of sampling is critical: later sampling (third day or later) is probably preferable to sampling on admission..$^{21}$ Of the factors measured to date, only $\mathrm{BNP}^{64}$ and NT-ANP ${ }^{65}$ have the predictive accuracy required (with a sensitivity of over $80 \%$ ) for identifying an echocardiographic ejection fraction of less than $40 \%$. Unfortunately, the normal range for these peptides varies considerably between laboratories and caution should be exercised in using published data for local clinical use. The reproducibility of echocardiographic ejection fraction is also questionable. ${ }^{66}$

Table 1 outlines the studies exploring the ability of neuroendocrine measurements to

Table 2 Predictive value of clinical and neuroendocrine indices after myocardial infarction

\begin{tabular}{|c|c|c|c|c|c|}
\hline Study & Variable & $\begin{array}{l}\text { Deaths/total < cut off } \\
100 \%-(\%)=P V N T\end{array}$ & $\begin{array}{l}\text { Deaths/total > cut off } \\
\text { with }(P V P T)\end{array}$ & Sensitivity & Specificity \\
\hline $\begin{array}{l}\text { Svanegaard } 1992^{57} \\
\text { Omland } 1993^{60}\end{array}$ & $\begin{array}{l}\text { ANF } \\
\text { Killip class } \\
\text { ANF }\end{array}$ & $\begin{array}{l}3 / 22(14 \%) \\
4 / 24(17 \%) \\
2 / 73(3 \%)\end{array}$ & $\begin{array}{l}16 / 33(48 \%) \\
15 / 31(48 \%) \\
15 / 72(21 \%)\end{array}$ & $\begin{array}{l}84 \% \\
70 \% \\
88 \%\end{array}$ & $\begin{array}{l}53 \% \\
56 \% \\
55 \%\end{array}$ \\
\hline Omland $1993^{61}$ & NT-ANF & $2 / 56(4 \%)$ & $13 / 83(16 \%)$ & $87 \%$ & $44 \%$ \\
\hline Rouleau $1994^{62}$ & $\begin{array}{l}\text { Heart failure } \\
\text { ANF } \\
\text { Endothelin } \\
\text { LVEF } \\
\text { Renin } \\
\text { Aldosterone } \\
\text { Noradrenaline } \\
\text { Adrenaline } \\
\text { Dopamine } \\
\text { ANP } \\
\text { ADH }\end{array}$ & $\begin{array}{c}10 / 103(10 \%) \\
4 / 73(6 \%) \\
8 / 73(8 \%) \\
2 / 43(5 \%) \\
56 / 421(10 \%) \\
40 / 333(12 \%) \\
59 / 414(14 \%) \\
76 / 492(15 \%) \\
33 / 406(15 \%) \\
16 / 203(8 \%) \\
54 / 388(14 \%)\end{array}$ & $\begin{array}{l}20 / 42(48 \%) \\
27 / 72(36 \%) \\
24 / 72(33 \%) \\
13 / 42(31 \%) \\
113(27 \%) \\
46 / 201(20 \%) \\
27 / 120(20 \%) \\
10 / 42(24 \%) \\
26 / 128(20 \%) \\
70 / 331(21 \%) \\
32 / 146(22 \%)\end{array}$ & $\begin{array}{l}67 \% \\
87 \% \\
79 \% \\
87 \% \\
35 \% \\
53 \% \\
31 \% \\
12 \% \\
30 \% \\
81 \% \\
37 \%\end{array}$ & $\begin{array}{l}81 \% \\
61 \% \\
58 \% \\
53 \% \\
81 \% \\
65 \% \\
79 \% \\
93 \% \\
77 \% \\
42 \% \\
75 \%\end{array}$ \\
\hline
\end{tabular}

PVNT, predictive value of a negative test; PVPT, predictive value of a positive test; ANF, atrial natriuretic factor; NT, N-terminal; LVEF, left ventricular ejection fraction; ADH, antidiuretic hormone. 
predict prognosis. Table 2 shows the sensitivity, specificity, and predictive value for mortality based on neuroendocrine variables.

Plasma concentrations of ANF-and possibly endothelin-above the median identify half of the population that has a one-year mortality rate of $<5 \%$, even if the ejection fraction is low. ${ }^{62}$ Thus simple measurement of a neuroendocrine variable could identify a large part of the population which was at low risk and did not need further investigation. On the other hand, the mortality of patients with ANF above the median is probably about $20 \%$ at one year. This would appear to be a population at sufficiently high risk to warrant aggressive management.

Currently only NT-ANF has been suggested to carry prognostic information over and above ventricular ejection fraction. However, it is possible that some neuroendocrine variables may be simpler and less expensive to measure than ejection fraction, in which case the onus would be on the latter to prove predictive superiority.

Another possibility is that a large proportion of patients with ventricular dysfunction are at low risk of events. Can neuroendocrine measurements supplement the information contained in the ejection fraction? Data from the SAVE study would suggest so. ${ }^{62}$ Of 534 patients with an ejection fraction of $<40 \%$, only $86(16 \%)$ died during follow up. Thirty eight per cent of this population had a plasma ANF in the normal range. Cardiovascular mortality in these patients was only $4 \%$ at one year compared to $12 \%$ in those with raised ANF $(P<0.005)$.

\section{Conclusion}

Studying and understanding neuroendocrine activation after myocardial infarction and in heart failure is likely to lead to greater insights into the pathophysiology of disease and hopefully to the development of better treatment. Neuroendocrine activation also has a potentially important role in diagnosis, monitoring treatment, and evaluating prognosis in patients with ventricular dysfunction and heart failure. However, much more clinical data are required before measurement of neuroendocrine variables can be recommended in clinical practice. Measurement of NT-ANF can be performed on routine blood specimens, ${ }^{67}$ unlike most other neuroendocrine variables, and hence is more likely to be useful in clinical practice. As many doctors would consider that all patients with major ventricular dysfunction or heart failure should have an echocardiogram to define the nature of the cardiac damage anyway, neuroendocrine markers should be scrutinised for their ability to rule out ventricular dysfunction rather than to detect it.

Thank you to John $M$ Boyle (Paterson Institute, Manchester) and Sassan Hafizi (Heart Science Centre, Harefield Hospital) for providing cultured cells.

1 McAlpine HM, Morton JJ, Leckie B, Rumley A, Gillen G Dargie HJ. Neuroendocrine activation after acute myocardial infarction. Br Heart f 1988;60:1 17-24.
2 Sigurdsson A, Held P, Swedberg K. Short- and long-term neurohormonal activation following acute myocardial infarction. Am Heart f 1993;126:1068-76.

3 McMurray J, Lang CC, MacLean D, McDevitt DG, Struthers AD. Neuroendocrine changes post myocardial infarction: effects of xamoterol. Am Heart $\mathcal{f} 1990 ; 120$ : infarction.

4 Nabel EG, Topol EJ, Galeana A, Ellis SG, Bates ER, Werns SW, et al. A randomized placebo-controlled trial of combined early intravenous captopril and recombinant tissue-type plasminogen activator therapy in acute tissue-type plasminogen activator therapy in acute
myocardial infarction. $\mathcal{F}$ Am Coll Cardiol 1991;17:467-73.

5 Rouleau JL, de Champlain J, Klein M, Bichet D, Moye L, Packer M, et al. Activation of neurohumoral systems in postinfarction left ventricular dysfunction. $\mathcal{F} \mathrm{Am}$ Coll Cardiol 1993;22:390-8.

6 Vaughan DE, Lamas GA, Pfeffer MA. Role of left ventricular dysfunction in selective neurohumoral activation in the recovery phase of anterior wall acute myocardial infarction. Am F Cardiol 1990;66:529-32.

7 Bayliss J, Norell M, Canepa-Anson R, Sutton G, PooleWilson P. Untreated heart failure: clinical and neuroendocrine effects of introducing diuretics. Br Heart $\mathcal{f}$ 1987;57:17-22

8 Broqvist M, Dahlstrom U, Karlberg BE, Karlsson E, Marklund T. Neuroendocrine response in acute heart failure and the influence of treatment. Eur Heart $\mathcal{F} 1989$; 10:1075-83.

9 Remes J, Tikkanen I, Fyhrquist F, Pyorala K. Neuroendocrine activity in untreated heart failure. $\mathrm{Br}$ Heart $\mathcal{f}$ 1991;65:249-55.

10 Francis GS, Benedict C, Johnstone DE, Kirlin PC, Nicklas $\mathrm{J}$, Liang CS, et al. Comparison of neuroendocrine activation in patients with left ventricular dysfunction with and tion in patients with left ventricular dysfunction with and
without congestive heart failure. A substudy of the without congestive heart failure. A substudy of the
Studies of Left Ventricular Dysfunction (SOLVD) Studies of Left Ventricular
Circulation 1990;82:1724-9.

11 Ullman B, Hulting J, Lundberg JM. Prognostic value of plasma neuropeptide-Y in coronary care unit patients with and without acute myocardial infarction. Eur Heart $\mathcal{F}$ 1994;15:454-61.

12 Omland T, Opstad K, Dickstein K. Plasma neuropeptide Y levels in the acute and early convalescent phase after myocardial infarction. Am Heart f 1994;127:774-9.

13 McCance AJ, Thompson PA, Forfar JC. Increased cardiac sympathetic nervous activity in patients with unstable coronary heart disease. Eur Heart $\mathcal{f} 1993 ; 14: 751-7$.

14 Fontana F, Bernardi P, Spagnolo N, Capelli M. Plasma atrial natriuretic factor in patients with acute myocardial infarction. Eur Heart f 1990;11:779-87.

15 Tomoda H. Plasma endothelin-1 in acute myocardia infarction with heart failure. Am Heart $\mathcal{f}$ 1993;125: 667-72.

16 Ray SG, McMurray JJ, Morton J, Dargie HJ. Circulating endothelin in acute ischaemic syndromes. Br Heart $\mathcal{F}$ 1992;67:383-6.

17 Lechleitner P, Genser N, Mair J, Maier J, Artner-Dworzak $\mathrm{E}$, Dienstl $\mathrm{F}$, et al. Plasma immunoreactive endothelin in the acute and subacute phases of myocardial infarction in the acute and subacute phases of myocardial infarction in patients

18 Lechleitner P, Genser N, Mair J, Maier J, Artner-Dworzak $\mathrm{E}$, Dienstl F, et al. Endothelin-1 in patients with complicated and uncomplicated myocardial infarction. Clin Invest 1992;70:1070-2.

19 Stewart DJ, Kubac G, Costello KB, Cernacek P. Increased plasma endothelin-1 in the early hours of acute myocardial infarction. $7 \mathrm{Am}$ Coll Cardiol 1991;18:38-43.

20 Ray SG, Morton JJ, Dargie HJ. Neuroendocrine activation and markers of early reperfusion in the acute phase of myocardial infarction. Eur Heart $\mathcal{f}$ 1993;14:1615-21.

21 Morita E, Yasue H, Yoshimura M, Ogawa H, Jougasaki $M$, Matsumura $\mathrm{T}$, et al. Increased plasma levels of brain natriuretic peptide in patients with acute myocardial infarction. Circulation 1993;88:82-91.

22 Phillips PA, Sasadeus J, Hodsman GP, Horowitz J, Saltups A, Johnston CI. Plasma atrial natriuretic peptide in patients with acute myocardial infarction: effects of streptokinase. Br Heart f 1989;61:139-43.

23 Sigurdsson A, Held P, Swedberg K, Wall B. Neurohormonal effects of early treatment with enalapril after acute myocardial infarction and the impact on left ventricular remodelling. Eur Heart $\mathcal{f}$ 1993;14:11 10-7.

24 Motwani JG, McAlpine H, Kennedy N, Struthers AD. Plasma brain natriuretic peptide as an indicator for angiotensin-converting-enzyme inhibition after myocardial infarction. Lancet 1993;341:1109-13.

25 Ngo L, Vesely DL, Bissett JK, Murphy ML, Dinh H, Sallman AL, et al. Acute and sustained release of the atrial natriuretic factor prohormone N-terminus with actial matriuretic factor prohormone acute myor

26 Kettunen RV, Leppaluoto J, Jounela A, Vuolteenaho O Plasma N-terminal atrial natriuretic peptide in acute Plasma N-terminal atrial natriuretic peptide in acut

27 Lerman A, Gibbons RJ, Rodeheffer RJ, Bailey KR, McKinley LJ, Heublein DM, et al. Circulating N-terminal atrial natriuretic peptide as a marker for symptomles left-ventricular dysfunction. Lancet 1993;341:1105-9.

28 Hall C, Rouleau JL, Moye L, de Champlain J, Bichet D, Klein $\mathrm{M}$, et al. N-terminal proatrial natriuretic factor: an independent predictor of long-term prognosis afte

myocardial infarction. Circulation 1994;89:1934-42.
29 Sun Y, Weber KT. Angiotensin II receptor binding follow- 
ing myocardial infarction in the rat. Cardiovasc Res 1994; 28:1623-8.

30 Falkenhahn M, Franke F, Bohle RM, Zhu YC, Stauss HM, Bachmann S, et al. Cellular distribution of angiotensinconverting enzyme after myocardial infarction. Hypertension 1995;25:219-26.

31 Nio Y, Matsubara H, Murasawa S, Kanasaki M, Inada $M$ Regulation of gene transcription of angiotensin II receptor
subtypes in myocardial infarction. $\mathcal{F}$ Clin Invest 1995; 95:46-54.

32 Shyu KG, Chen JJ, Shih NL, Chang H, Wang DL, Lien WP, et al. Angiotensinogen gene expression is induced by cyclical mechanical stretch in cultured rat cardiomyocytes. Biochem Biophys Res Commun 1995;211:241-8.

33 Weber KT, Sun Y, Tyagi SC, Cleutjens JP. Collagen network of the myocardium: function, structural remodelling and regulatory mechanisms. F $\mathrm{Mol}$ Cell Cardiol 1994:26:279-92.

34 Whittaker P, Boughner DR, Kloner RA. Role of collagen in acute myocardial infarct expansion. Circulation 1991:84: 2123-34

35 Neuss M, Regitz-Zagrosek V, Hildebrandt A, Fleck E. Human cardiac fibroblasts express an angiotensin receptor with unusual binding characteristics which is coupled to cellular proliferation. Biochem Biophys Res Commun 1994: 204:1334-9.

36 Stoll M, Steckelings UM, Paul M, Bottari SP, Metzger R, Unger $T$. The angiotensin AT2-receptor mediates inhibition of cell proliferation in coronary endothelial cells. $\mathcal{f}$ Clin Invest 1995;95:651-7.

37 Michorowski B, Ceremuzynski L. The renin-angiotensinaldosterone system and the clinical course of acute myocardial infarction. Eur Heart f 1983;4:259-64.

38 Batin PD, Hawkins M, Cowley AJ. Patterns of neuroendocrine activation at rest and during exercise following acute myocardial infarction. Eur Heart $\mathcal{f}$ 1994;15: acute m52-7.

39 Motwani JG, Fenwick MK, McAlpine HM, Kennedy N, Struthers AD. Effectiveness of captopril in reversing renal vasoconstriction after Q-wave acute myocardial infarction. Am f Cardiol 1993;71:281-6.

40 Tomoda $\mathrm{H}$. Atrial natriuretic peptide in acute myocardial infarction. Am $\mathcal{F}$ Cardiol 1988;62:1122-3.

41 Robalino BD, Petrella RW, Jubran FY, Bravo EL, Healy BP, Whitlow PL. Atrial natriuretic factor in patients with right ventricular infarction. $\mathcal{F} \mathrm{Am}$ Coll Cardiol 1990;15: 546-53.

42 Cleland JG, Oakley CM. Vascular tone in heart failure: the neuroendocrine-therapeutic interface. Br Heart $\mathcal{F} 1991$; 66:264-7.

43 Cleland JG, Dargie HJ. Heart failure, renal function, and angiotensin converting enzyme inhibitors. Kidney Int Suppl 1987;20:S220-8.

44 Puri S, Baker BL, Dutka DP, Oakley CM, Hughes JM, Cleland JG. Reduced alveolar-capillary membrane diffusing capacity in chronic heart failure. Its pathophysiological relevance and relationship to exercise performance. Circulation 1995;91:2769-74.

45 Cleland JG. ACE inhibitors for myocardial infarction: how should they be used? Eur Heart f 1995;16:153-9.

46 Cleland JG, Gillen G, Dargie HJ. The effects of furosemide and angiotensin-converting enzyme inhibitors and their and angiotensin-converting enzyme inhibitors and their combination on cardiac and renal haem

47 Cleland JG, Bulpitt CJ, Falk RH, Findlay IN, Oakley CM, Murray G, et al. Is aspirin safe for patients with heart failMurray G, et al. Is aspirin safe
ure? Br Heart $f$ 1995;74:215

48 Hirvonen T, Remes J, Mustonen J, Tikkanen I, Tenhunen $M$, Pyorala K. Effect of enalapril on plasma atrial natriuretic peptide in late recovery phase of acute myocardial infarction. Ann Intern Med 1991;23:271-5.

49 Kingma JH, van Gilst WH, Peels CH, Dambrick JH, Verheugt FW, Wielenga RP. Acute intervention with captopril during thrombolysis in patients with first anterior myocardial infarction. Results from the Captopril and Thrombolysis Study (CATS). Eur Heart 7 1994;15: 898-907.

50 Huttl $S$, Nussberger J, Lehmann $K$, Hasford J, Brunner HR, Delius W. Beneficial clinical effect of very early enalapril treatment in patients with acute left ventricular failure complicating myocardial infarction. Clin Cardiol 1995;18:317-23.

51 Omland T, Aarsland T, Aakvaag A, Dickstein K. The effect of early converting enzyme inhibition on neurohumoral activation in acute myocardial infarction. Int $\mathcal{f}$ Cardiol 1993;42:37-45.

52 Bonarjee VV, Omland T, Nilsen DW, Carstensen S, Berning J, Edner M, et al. CONSENSUS II Multi-Echo Study Group. Left ventricular volumes, ejection fraction, and plasma proatrial natriuretic factor (1-98) after withdrawal of enalapril treatment initiated early after myocardial infarction. Br Heart $\mathcal{f} 1995 ; 73: 506-10$.

53 Pinto YM, van Gilst WH, Kingma JH, Schunkert $H$. Captopril and Thrombolysis Study Investigators. Deletion-type allele of the angiotensin-converting Deletion-type allele of the angiotensin-converting dilation after anterior myocardial infarction. $¥ \mathrm{Am}$ Coll dilation after anterior my

54 Cleland JG. ACE inhibitors: current understanding and future directions. Br Heart $\mathcal{f} 1994 ; 72: S 1$

55 Dossegger L, Aldor E, Baird MG, Braun S, Cleland JG, Donaldson $\mathrm{R}, \mathrm{et}$ al. Influence of angiotensin converting enzyme inhibition on exercise performance and clinical symptoms in chronic heart failure: a multicentre, doubleblind, placebo-controlled trial. Eur Heart $\mathcal{f} 1993 ; 14$ suppl C: $18-23$.

56 Cleland JGF, Puri S. How do ACE inhibitors reduce mortality in patients with left ventricular dysfunction with and without heart failure: remodelling, resetting, or sudden death? Br Heart $\mathcal{F}$ 1994;72:S81-6.

57 Svanegaard J, Angelo-Nielsen K, Pindborg T. Plasma concentration of atrial natriuretic peptide at admission and risk of cardiac death in patients with acute myocardial infarction. Br Heart f 1992:68:38-42.

58 Omland T, Bonariee VV, Lie RT, Caidahl K. Neurohumoral measurements as indicators of long-term prognosis after acu

59 Omland T, Lie RT, Aakvaag A, Aarsland T, Dickstein K. Plasma endothelin determination as a prognostic indicator of 1-year mortality after acute myocardial infarction. $4: 89 \cdot 1573-9$

60 Omland T, Aarsland T, Aakvaag A, Lie RT, Dickstein K. Prognostic value of plasma atrial natriuretic factor, norepinephrine and epinephrine in acute myocardial infarction. Am f Cardiol 1993;72:255-9.

61 Omland T, Bonarjee VV, Nilsen DW, Sundsfjord JA, Lie RT, Thibault G, et al. Prognostic significance of N-terminal pro-atrial natriuretic factor $(1-98)$ in acute myocardial infarction: comparison with atrial natriuretic factor (99-126) and clinical evaluation. Br Heart $f$ 1993;70:409-14

62 Rouleau JL, Packer M, Moye L, de Champlain J, Bichet D, Klein $M$, et al.Prognostic value of neurohumoral activation in patients with an acute myocardial infarction: effect of captopril. I Am Coll Cardiol 1994;24:583-91.

63 Arakawa N, Nakamura N, Aoki H, Moriai N, Suzuki T, Hiramori K. Prognostic value of plasma brain natriuretic peptide concentration in patients with acute myocardial infarction [abstr]. Circulation 1994;90(suppl 1):279.

64 Choy AM, Darbar D, Lang CC, Pringle TH, McNeill GP Kennedy NS, et al. Detection of left ventricular dysfunction after acute myocardial infarction: comparison of clinical, echocardiographic, and neurohormonal methods. Br Heart $¥$ 1994;72:16-22.

65 Bonarjee VV, Omland T, Nilsen DW, Caidahl K, Sundsfiord JA, Dickstein K. Plasma proatrial natriuretic factor (1-98) concentration after myocardial infarction: relation to indices of cardiac and renal function. Br Heart f 1995;73:511-6.

66 Ray SG, Metcalfe MJ, Oldroyd KG, Pye M, Martin W, Christie J, et al. Do radionuclide and echocardiographic techniques give a universal cut off value for left ventricular ejection fraction that can be used to select patients for treatment with ACE inhibitors after myocardial infarction? Br Heart $\mathcal{F}$ 1995; 73:466-9.

67 Cleland JGF, Ward S, Dutka D, Habib F, Impallomeni M, Morton IJ. Stability of plasma concentrations of N- and -terminal atrial natriuretic peptides at room temperature. Br Heart f 1996;75:410-3.

68 Omland T, Aakvaag A, Bonarjee VVS, Caidahl K, Lie RT, Nilsen DWT, et al. Plasma brain natriuretic peptide as an indicator of left ventricular systolic function and longterm survival after acute myocardial infarction: comparison with plasma atrial natriuretic peptide and N-terminal proatrial natriuretic peptide. Circulation 1996;93:1963-9. 